\title{
The effects of machiavellian, equity sensitivity, and ethical sensitivity on the accounting students' ethical perceptions in perceiving the accountants' ethics
}

\author{
Irodatun Nadilla, Dodik Juliardi* \\ Universitas Negeri Malang, Jl. Semarang No. 5 Malang, Jawa Timur, Indonesia \\ *Corresponding author, Surel: dodik.juliardi.fe@um.ac.id
}

Paper received: 2-2-2021; revised: 20-2-2021; accepted: 27-2-2021

\begin{abstract}
This study aims to examine the effect of Machiavellian, equity sensitivity, ethical sensitivity on the ethical perceptions of accounting students in perceiving the ethical behavior of accountants. The sampling method that used is proportional sampling. The participants of this study are S1/ D4 students from accounting study program in the level of 2016 at the State Universities (PTN) and the Private Universities (PTS) accredited A in Malang. The samples of this study were 381 accounting students from eight universities. The data analysis that used in this study is multiple linear regression. The results showed that Machiavellian had a positive effect on the accounting students' ethical perceptions of the accountant's ethical behavior, equity sensitivity had no effect on the accounting students' perceptions of the accountant's ethical behavior, and ethical sensitivity had a positive effect on the accounting students' ethical perceptions of the accountant's ethical behavior.
\end{abstract}

Keywords: machiavellian; equity sensitivity; ethical sensitivity; ethical perception of accounting students

\section{Introduction}

The accounting profession ethics is a science that discusses human good and bad behavior that can be understood by the human mind towards work that requires mastery and training for a specific knowledge as an Accountant. Accounting scandals that occur hurt the image of the accounting profession. As a prospective accountant, the reactions and perceptions of prospective accountants (students) are significant.

Accounting students will undergo the profession of accountants (prospective accountants) where if their attention to the field of ethics and ethical violations from an early age is low, it will damage the accounting profession of the future. Phenomenon or examples of cases of ethical violations that have occurred are the case of AP Marlinna and AP Merliyana Syamsul and KAP Satrio, Bing, Eny (SBE) and Partners they are considered not to give opinions by the actual conditions in the annual financial report of the audit of PT Sunprima Nusantara Financing (SNP Finance). Both the AP and one KAP gave the opinion 'Fair without exceptions.' The results of the 0JK examination indicate SNP Finance presents financial statements that are not following the actual financial condition, causing losses to many parties, including banks. Violates POJK Number 13/POJK.03/2017 regarding the use of public accounting services and public accounting firms. Sanctions received by the two APs and one KAP were in the form of cancellation of registration related to the results of the examination of SNP Finance's financial statements. KAP SBE is also prohibit from adding new clients. As for AP Marlinna and AP Merliyana Syamsul, the cancellation of the registration is effective since the FSA was set on Monday (1/10). (Tirto.id, 2018)

This work is licensed under a Creative Commons Attribution-ShareAlike 4.0 International License. 
In acting, a person has the factors that cause him to do the action. Likewise, in determining ethical perceptions, a person will take action to deal with the problems that occur. The theory of cognitive moral development is a determining factor in ethical decision making. According to Piaget, cognitive development is the growth of logical thinking from infancy to adulthood (Winarno, 2014). Cognitive moral development theory emphasizes moral thinking, which is about what is thought by an individual in the face of an ethical dilemma. Kohlberg believes that the level of moral development has three levels, where each level consists of two stages so that the overall moral development of individuals goes through six moral stages (Moshman, 2011)

Machiavellian is a trait that tends to make an individual assume that he can do, however, so that the goal reached even if it is wrong (Asmara, 2007). As in the fraud triangle by Cressey, the reason for rationalization allows the perpetrators of fraud to believe that they did not make mistakes, and they are ordinary people (Reding et al. ,2013) so that it makes the perpetrators ignore ethical attitudes. In line with Devi \& Ramantha (2017) research, which states that machiavellian has a positive and significant effect on auditor's dysfunctional behavior. However, research conducted by Nikara \& Mimba (2019) states that machiavellian hurts the ethical perceptions of accounting students.

Besides machiavellian, another factor that thought out to influence ethical perception is equity sensitivity. Equity sensitivity is as a personality variable that shows an individual's reaction when he feels fair or unfair (Huseman, Hatfield \& Miles, 1987). According to Huseman et al., (in Allen et al., 2015), each individual can be categorized into three categories, namely benevolent (givers), equity sensitivity, and entitles (getters). Equity sensitivity is between benevolent (givers) and entitles (getters), which illustrates the individual's perception of the balance between input and outcome. The results of Sari \& Widanaputra (2019) research suggest that equity sensitivity has a positive effect on students' ethical perceptions. However, this research is not in line with research conducted by Asih \& Dwiyanti (2019), which suggests that equity sensitivity cannot affect the ethical behavior of taxpayers in terms of fulfilling their tax obligations.

Another factor that thought out to influence ethical perception is ethical sensitivity. Ethical sensitivity is the ability to realize ethical values in a decision (Jones, 1991 in Febriyanti, 2010). Sensitivity emphasizes the sensitivity of a person to the values that occur in his environment. Febrianty (2010) states that students with good ethical sensitivity can minimize ethical code violations and give an appreciation for accountants who can carry out their duties professionally. This statement supported by the results of research conducted by Cahyani \& Ramantha (2018), stating that ethical sensitivity has a positive effect on the ethical perceptions of accounting students of the ethical behavior of accountants. However, different from research conducted by Fatmawati (2007) states that ethical behavior not affected by ethical sensitivity.

One of the objectives of this study is to discuss the applicability of moral development theory to the influence of machiavellian, equity sensitivity, and ethical sensitivity on the ethical perceptions of accounting students over the ethical perceptions of accountants. Based on the explanation above, the following hypotheses can make:

H1: Machiavellian negatively influences the accounting students' ethical perceptions of the ethical behavior of accountants. 
H2: Equity Sensitivity has a positive effect on the ethical perceptions of accounting students on accountants' ethical behavior.

H3: Ethical Sensitivity has a positive effect on ethical perception.

\section{Method}

This research is explanatory quantitative research. According to Ibnu et al. (in Alfianika, 2018: 20), analytical research is research in which data analysis comes to determine the relationship of one variable with another variable. The population used in this study were students of S1/D4 accounting year 2016 at the State University (PTN), and Private Universities (PTS) accredited A in Malang. The sampling method used is proportional sampling. In which in determining the sample, researchers take representatives from each group in the population whose number is adjusted by the number of subject members in each group. Determination of the number of samples using the formula Slovin. So as many as 381 students were obtained. The Slovin formula used is as follows:

$$
\begin{aligned}
n & =\frac{N}{1+\mathrm{N}(\mathrm{e}) 2} \\
\frac{1.764}{1+1.764(0,05) 2} & =380,52(\text { rounded up 381) }
\end{aligned}
$$

Information:

n: Sample size

N: Population Size

$e$ : Significance level of fault tolerance (0.05)

The 381 samples will then be scattered and divided into eight designated universities. The method for determining the number of samples per tertiary institution is as follows:

The number of samples per collage $=\frac{N}{\Sigma N} x \mathrm{n}$

Information:

$\mathrm{N}$ : Overall sample

N: Population Size

$\Sigma \mathrm{N}$ : Total Population

Then the number of samples per college is:

1. The number of UM samples $\frac{230}{1.764} \times 381=50$

2. The number of STIE Malangkucecwara samples $\frac{173}{1.764} \times 381=37$

Furthermore, the number of samples for other tertiary institutions counted in the same way. 
Table 1. Population and Samples

\begin{tabular}{rlcc}
\hline & \multicolumn{1}{c}{ Collage } & \multicolumn{1}{c}{$\begin{array}{c}\text { Number of } \\
\text { Accounting Students }\end{array}$} & $\begin{array}{c}\text { Number of Samples } \\
\text { (Proportional) }\end{array}$ \\
\hline 1. & Universitas Negeri Malang & 230 & 50 \\
2. & Universitas Brawijaya & 245 & 53 \\
3. & Universitas Islam Negeri & 121 & 26 \\
& Maulana Malik Ibrahim & & 51 \\
4. & Politeknik Negeri Malang & 238 & 84 \\
5. & Universitas Muhammadiyah & 389 & 50 \\
& Malang & & 30 \\
6. & Universitas Islam Malang & 230 & 37 \\
7. & Universitas Merdeka & 138 & 381 \\
8. & Sekolah Tinggi Ilmu Ekonomi & 173 & 30 \\
& Malangkucecwara & & \\
& Total & 1.764 & \\
\hline
\end{tabular}

The data collection technique used in this study uses data obtained through the distribution of questionnaires to respondents. The determination of the score will give to the items of the research statement in the questionnaire. The technical scale used to measure the statement items in this study is the Likert scale. The Likert scale used in the measurement of this study has modified with four alternative answers. According to Hadi (in Hertanto, 2017), the Likert scale's modification intended to eliminate weaknesses contained by the five-level scale, based on three reasons, namely: (1) The category has a double meaning, usually interpreted as neutral or not giving an answer. (2) The availability of answers in the middle raises answers to the middle, especially for those who are still in doubt. (3) Not used because it can eliminate the amount of information from respondents.

So in this study, positive answers were given values in succession 4, 3, 2, 1, and answers that were negative give values successively 1, 2, 3, 4 .

Table 2. Questionnaire Rating Scores

\begin{tabular}{llll}
\hline Positive Statement & & Negative Statement \\
\hline Answer & Score & Answer & Score \\
\hline Sangat Setuju & 4 & Sangat Setuju & 1 \\
Setuju & 3 & Setuju & 2 \\
Tidak Setuju & 2 & Tidak Setuju & 3 \\
Sangat Tidak Setuju & 1 & Sangat Tidak Setuju & 4 \\
\hline
\end{tabular}

In this study, the instrument used was a closed questionnaire in which answers were available so that respondents only needed to choose one of the answers provided.

Table 3. Research Instruments

\begin{tabular}{lll}
\hline $\begin{array}{l}\text { Variables and } \\
\text { Research Sources }\end{array}$ & Research Indicator & $\begin{array}{l}\text { Statement Item } \\
\text { Number }\end{array}$ \\
\hline Machiavellian & Immorality & $1-5$ \\
& Desire for control & $6-8$ \\
& Desire for status & $9-11$ \\
& Suspicion of others & $12-16$ \\
Equity Sensitivity & Entitled & $1^{*}, 2^{*}, 3^{*}, 4^{*}, 5^{*}, 6,7,8$ \\
& Benevolent & $9,10,11,12$ \\
\hline
\end{tabular}




\begin{tabular}{lll}
\hline $\begin{array}{l}\text { Variables and } \\
\text { Research Sources }\end{array}$ & Research Indicator & $\begin{array}{l}\text { Statement Item } \\
\text { Number }\end{array}$ \\
\hline Ethical Sensitivity & $\begin{array}{l}\text { Failure of the accountant in doing work in } \\
\text { accordance with the requested time } \\
\text { Use of office hours for personal use } \\
\text { The Subordinate judgment of accountants } \\
\text { in relation to accounting principles } \\
\text { Conflict of interest }\end{array}$ & 1 \\
& & 2 \\
\hline
\end{tabular}

Testing is done using multiple linear regression analysis analysis techniques. The multiple regression equation model used is as follows:

$$
Y=a-\beta 1 x 1+\beta 2 x 2+\beta 3 x 3+e
$$

Information:

$\mathrm{Y}=$ Ethical Decision

$a=$ Constant Coefficient

$\beta 1=$ Machiavellian Coefficient

$\beta 2=$ Equity Sensitivity Coefficient

$\beta 3=$ Ethical Sensitivity Coefficient

$x 1=$ Machiavellian

$x 2=$ Equity Sensitivity

$x 3=$ Ethical Sensitivity

$e=$ Error.

\section{Result and Discussion}

Descriptive statistical analysis is used to analyze data by describing the mean value, standard deviation (Std. Deviation), minimum value, and maximum value. Here is a table of descriptive statistical analysis results.

Table 4. Results of Descriptive Statistics Analysis

\begin{tabular}{lcccc}
\hline & Machiavellian & $\begin{array}{l}\text { Equity } \\
\text { Sensitivity }\end{array}$ & $\begin{array}{l}\text { Ethical } \\
\text { Sensitivity }\end{array}$ & $\begin{array}{l}\text { Persepsi Etis } \\
\text { Mahasiswa } \\
\text { Akuntansi }\end{array}$ \\
\hline N $\quad$ Valid & 381 & 381 & 381 & 381 \\
$\quad$ Missing & 0 & 0 & 0 & 0 \\
Mean & 34.30 & 31.87 & 7.83 & 11.71 \\
Std. & 7.285 & 3.775 & 1.597 & 2.866 \\
Deviation & 15 & 18 & 3 & 5 \\
Minimum & 60 & 43 & 12 & 20 \\
Maximum & & & & \\
\hline
\end{tabular}

Machiavellian (X1), the average value of 34.40, indicates that the answers of respondents tend to agree on the statement of machiavellian behavior. It can say that machiavellian behavior tends to be high. The standard deviation of the machiavellian variable is 7.285. Shows that the standard deviation of the data against the average value is 7.285 . The minimum value of the machiavellian variable is 15 , and the maximum value is 60 .

Equity sensitivity (X2) the average value of 31.87 indicates that the answers of respondents tend to agree on the statement of equity sensitivity; it can say that equity sensitivity tends to be high. The standard deviation of the equity sensitivity variable is 3.775 . 
Shows that the standard deviation of the data against the average value is 3.775 . The minimum value of the equity sensitivity variable is 18 , and the maximum value is 43 .

Ethical sensitivity (X3) is an average value of 7.83, indicating that the answers of respondents tend to agree with the statement of ethical sensitivity; it can say that ethical sensitivity tends to be high. The standard deviation of the ethical sensitivity variable is 1.597. Shows that the standard deviation of the data against the average value is 1.597. The minimum value of the ethical sensitivity variable is 3 , and the maximum value is 12 .

Ethical Perception of Accounting Students (Y) The average value of 11.71 indicates that the respondents' answers tend to agree on the statement of ethical perceptions of accounting students. It can say that the ethical perceptions of accounting students tend to be high. The standard deviation of the ethical perception variable of accounting students is 2.866 . Shows that the standard deviation of the data against the average value is 2.866 . The minimum value of the ethical perception variable of accounting students is 5 , and the maximum value is 20 .

In the data analysis model in this study, the independent variables used were Machiavellian (X1), Equity Sensitivity (X2), and Ethical Sensitivity (X3). While used as the dependent variable in this study is the Ethical Perception of Accounting Students (Y). The results of multiple linear regression can be seen in Table 5. as follows.

Table 5. Multiple Linear Regression Test Results

\begin{tabular}{|c|c|c|c|c|c|}
\hline \multirow{2}{*}{$\frac{\text { Model }}{\mathrm{B}}$} & \multicolumn{2}{|c|}{$\begin{array}{l}\text { Unstandardized } \\
\text { Coefficients }\end{array}$} & \multirow{2}{*}{$\begin{array}{l}\begin{array}{l}\text { Standardized } \\
\text { Coefficients }\end{array} \\
\text { Beta }\end{array}$} & \multirow[t]{2}{*}{$\mathbf{t}$} & \multirow[t]{2}{*}{ Sig. } \\
\hline & & Std. Error & & & \\
\hline (Constant) & 5,775 & 1,492 & & 3,872 & 000 \\
\hline Machiavellian & ,078 & ,020 & 197 & 3,934 & 000 \\
\hline $\begin{array}{l}\text { Equity } \\
\text { Sensitivity }\end{array}$ & -016 & 037 & -021 & -434 & 665 \\
\hline $\begin{array}{l}\text { Ethical } \\
\text { Sensitivity }\end{array}$ & 483 & 089, & 269, & 5,419 & 000 \\
\hline
\end{tabular}

Based on the results of the multiple regression analysis above, the regression equation can make as follows:

Keterangan :

$Y=5,775+0,078 \mathrm{X} 1-0,016 \mathrm{X} 2+0,483 \mathrm{X} 3+e$

$\mathrm{Y}=$ Ethical Perception of Accounting Students

$\mathrm{X} 1=$ Machiavellian

$\mathrm{X} 2=$ Equity Sensitivity

$\mathrm{X} 3=$ Ethical Sensitivity

$\mathrm{e}=$ Error (other variables not explained in the study)

Based on the F test results in Table 5. it can be seen the significance value of $0,000<0.05$ and Fcount 20.666>2.65, so there is an influence of machiavellian variables, equity sensitivity, and ethical sensitivity on the dependent variable ethical perceptions of accounting students as a whole (simultaneous). The coefficient of determination (R2) in Table 5. is equal to 0.141 or equal to $14.1 \%$. It can explain that machiavellian, equity sensitivity, and ethical sensitivity affect the ethical perceptions of accounting students by $14.1 \%$, while other variables outside this study influence the rest. 
The t-test uses to test the effect of independent variables on the dependent variable, whether by the allegations hypothesized by researchers (Siregar, 2013: 194). The t-test can see by comparing the value of tcount with ttable, which is tcount $>$ ttable, which means there is an influence between the independent variables on the dependent variable. The results of the partial test calculations were then compared with a table using a significance of 0.05 . If the significant value> 0.05 , then $\mathrm{H} 0$ is accepted, and Ha is not being accepted. Conversely, if a significant value $<0.05$, then $\mathrm{H} 0$ is not being accepted and $\mathrm{Ha}$ is accepted.

Based on Table 5., the significance value of the t-test for the variable influence of machiavellian on the ethical perceptions of accounting students on the ethical behavior of accountants is $0,000<0.05$ and tcount 3,934> 1,971. Shows that machiavellian has a positive effect on the accounting students' ethical perceptions of the ethical behavior of accountants. Based on Table 5., the significance value of the t-test for the variable influence of equity sensitivity on the accounting students' ethical perceptions of the ethical behavior of accountants is $0.665>0.05$ and tcount $-0.434<1.971$. Shows that there is no effect of equity sensitivity on the accounting students' ethical perceptions of the ethical behavior of accountants. Based on Table 5., the significance value of the t-test for the variable influence of ethical sensitivity on the accounting students' ethical perceptions of the ethical behavior of accountants, which is $0,000<0.05$ and tcount $5.419>1.971$. Shows that ethical sensitivity has a positive effect on the accounting students' ethical perceptions of the ethical behavior of accountants.

\subsection{Effect of Machiavellian on Ethical Perceptions of Accounting Students on the Ethical Behavior of Accountants}

The results of data analysis showed that machiavellian had a positive effect on the ethical perceptions of accounting students. Based on this, it means that the higher the machiavellian nature of accounting students, the higher the ethical perceptions, the lower the machiavellian nature of accounting students, the lower the ethical perceptions. From these results, it can conclude that $\mathrm{H} 1$ not being accepted. Namely, machiavellian hurts the ethical perceptions of accounting students on accountants' ethical behavior. These results support previous research conducted by Prabowo \& Widanaputra (2018), Saitri \& Suryandari (2017), and Richmond (2001), who stated that the higher machiavellian level, the lower the ethical perception. However, it does not support research conducted by Sari \& Widanaputra (2019), Nikara \& Mimba (2019), Kurniawan \& Anjarwati (2019), which states that machiavellian nature negatively influences the ethical perceptions of accounting students.

The results of this study are by the theory of cognitive moral development in the first stage, which is an ethical or unethical action taken for personal gain and depends on motivation in a person as well as fear of punishment/regulation that can harm himself. According to Kohlberg (in Nida, 2013), 1 and 2 stages of this theory of cognitive moral development occur in children aged 4-10 years, but adults can also show this at this stage. Accounting students in eight Malang universities accredited A use as samples in this study aged 21-23 years, which can be said to be an adult in age. The age range should be including in stages 5 and 6 , usually between 13 years and over. The fact is, according to the results of the study, it turns out accounting students in eight Malang accredited A universities still have morals like children aged 4-10 years, so this does not support ethical perception which results in the hypothesis not being accepted. 


\subsection{Effect of Equity Sensitivity on the Ethical Perceptions of Accounting Students on the Ethical Behavior of Accountants}

The results of the data analysis show that equity sensitivity does not affect the ethical perceptions of accounting students. It means that the high or low ethical perceptions of accounting students not influenced by equity sensitivity. From these results, it can conclude that $\mathrm{H} 2$ is not being accepted, namely equity sensitivity has a positive effect on the ethical perceptions of accounting students of the ethical behavior of accountants. This study supports the research conducted by Susanti (2014), which states that equity sensitivity does not have a significant effect on an accountant's ethical behavior. However, it does not support research conducted by Sari \& Widanaputra (2019), which states that equity sensitivity has a positive effect on students' ethical behavior.

This study's results indicate that the ethical perceptions of accounting students are not influenced by what they spend and get. It is inversely proportional to some previous research stating that equity sensitivity has a positive effect on accounting students' ethical perceptions. Accounting students in eight Malang universities accredited A tend to have personalities who prefer the input ratio; they get the same as the people around them. Accounting students in eight Malang universities accredited A is the personality type who will keep trying to work their best and remain professional by the code of ethics. Such individuals are also not included in the Benevolent or Entitled category because they do not compare the outcomes and the inputs that will get. Individuals like this tend to have high motivation in solving problems of negative inequity or positive inequity.

Based on these results, this study is not by the theory of cognitive moral development, stage 2; if they are useful to others, other people will be good to them. According to Kohlberg (in Nida, 2013), stage 2 is the stage experienced by children aged 4-10 years. In this study, some respondents showed more moral development at the 3rd stage, which usually occurs in children aged 10-13 years; namely, ethical behavior is a behavior that is pleasant or helps others. For this reason, accounting students in eight Malang accredited A universities do not think about their outcomes and inputs as being the same. However, they expect the input they get is the same as that obtained by others around him. So, it can conclude that equity sensitivity does not affect the accounting students' ethical perceptions of the ethical behavior of accountants.

\subsection{Effect of Ethical Sensitivity on the Ethical Perceptions of Accounting Students on the Ethical Behavior of Accountants}

The results of the data analysis show that ethical sensitivity has a positive effect on accounting students' ethical perceptions. Based on this, it means that the higher ethical sensitivity possessed by accounting students, the higher ethical perception will be. Likewise, the lower ethical sensitivity of accounting students, ethical perceptions is lower. From these results, it can conclude that $\mathrm{H} 3$ is accepted. Ethical sensitivity has a positive effect on the ethical perceptions of accounting students of the ethical behavior of accountants. These results support previous research conducted by Askandar \& Mahsuni (2019), Cahyani \& Ramantha (2018), which states that ethical sensitivity has a positive effect on ethical behavior. However, it does not support research conducted by Chan \& Leung (2006). 
Ethical sensitivity is the ability/sensitivity of a person to ethical values in making decisions on an event that takes place in their environment. Accounting students who have high ethical sensitivity or knowledge of ethical values when making a decision will be more ethical behavior of the accounting students because before they do an action, they will think in advance whether the action will be carried out or not. Also, accounting students with high ethical sensitivity will be aware of deviant behavior in their environment so that they will take ethical action. Sensitivity to deviant actions will protect someone from actions that can harm others. Thus, they will respect their colleagues who can obey the applicable ethics rather than those who do not.

The theory of cognitive moral development, in this case, plays a role in the ethical perceptions of accounting students, that is, following public order, law, justice, and obligation so that decisions made on an event will be by ethical values prevailing in the surrounding environment. According to Kohlberg (in Nida, 2013), this stage occurs in the age range of 1013 years. Based on this, the age of the respondent does not fit into this stage. However, these results reflect that there are some students whose moral development has reached stage 4 . While rest is still at the level below it, this can see from the results of the t-test that has carried out; only $5 \%$ of ethical sensitivity can increase the ethical perceptions of accounting students. This study there is a link between cognitive moral development theory and ethical sensitivity, although only slightly

\section{Conclusion}

Based on the results of research and discussion, there are two conclusions about the influence of machiavellian, equity sensitivity, and ethical sensitivity on the ethical perceptions of accounting students on the ethical behavior of accountants. First, the ethical perceptions of accounting students at Malang State University, Brawijaya University, Maulana Malik Ibrahim State Islamic University, Malang State Polytechnic, Malang Muhammadiyah University, Malang Islamic University, Merdeka University, and Malangkucecwara College of Economics on the ethical behavior of accountants was only influenced by Ethical Sensitivity especially on indicators of accountant failure in doing work by the requested time. Secondly, most accounting students at Malang State University, Brawijaya University, Maulana Malik Ibrahim State Islamic University, Malang State Polytechnic, Malang Muhammadiyah University, Malang Islamic University. Merdeka University, and Malangkucecwara College of Economics are still at a stage of moral development. Stage 3, means that ethical perceptions are low, so it does not support a decrease in ethical violations. The limitations of this research are that the research is only limited to Machiavellian, Equity Sensitivity, and Ethical Sensitivity in influencing the ethical perceptions of accounting students on the ethical behavior of accountants. The coefficient of determination of the three is 0.141 or has an effect of $14.1 \%$, thus indicating the number of other factors that can influence the ethical perceptions of accounting students of the ethical behavior of accountants.

\section{References}

Afriani, M., Askandar, N. S., \& Mahsuni, A. W. (2019). Pengaruh Gender, Ethical Sensitivity, Locus of Control dan Pemahaman Kode Etik Profesi Akuntan terhadap Perilaku Etis Mahasiswa Akuntansi Universitas Islam Malang. Jurnal Ilmiah Riset Akuntansi, 8(03), 12-28.

Allen, R. S., Allen, D. E., Karl, K., \& White, C. S. (2015). Are Millennials Really an Entitled Generation? An Investigation into Generational Equity Sensitivity Differences. Journal of Business Diversity, 15(2), 1426.

Alfianika, N. (2018). Buku ajar metode penelitian pengajaran bahasa Indonesia. Deepublish. 
Asih, N. P. S. M., \& Dwiyanti, K. T. (2019). Pengaruh Love of Money, Machiavellian, dan Equity Sensitivity terhadap Persepsi Etika Penggelapan Pajak (Tax Evasion). E-Jurnal Akuntansi, 26(2), 1412-1435. https://doi.org/https://doi.org/10.24843/EJA.2019.v26.i02.p21

Asmara, R. Y. (2017). Analysis of Effect of Love of Money, Machiavellian, and Gender Properties on Ethical Perception of Accounting Students. Research Journal of Finance and Accounting, 8(14), 1-9.

Chan, S. Y., \& Leung, P. (2006). The effects of accounting students' ethical reasoning and personal factors on their ethical sensitivity. Managerial auditing journal, 21(4), 436-457. https://doi.org/10.1108/02686900610661432

Devi, N. P. A., \& Ramantha, I. W. (2017). Tekanan Anggaran Waktu, Locus of Control, Sifat Machiavellian, Pelatihan Auditor Sebagai Anteseden Perilaku Disfungsional Auditor. E-Jurnal Akuntansi, 18(3), 23182345.

Fatmawati, N. D. (2007). Analisis Pengaruh Faktor-Faktor Individual Terhadap Perilaku Etis Auditor Di KAP (Survey pada Auditor di Kantor Akuntan Publik Yogyakarta dan Surakarta) (Doctoral dissertation, Universitas Muhammadiyah Surakarta)

Febrianty, F. (2010). Pengaruh Gender, Locus of Control, Intellectual Capital, dan Ethical Sensitivity Terhadap Perilaku Etis Mahasiswa Akuntansi pada Perguruan Tinggi (Survey pada Perguruan Tinggi di Kota Palembang). Jurnal Ilmiah Orasi Bisnis, IV (ISSN: 2085-1375), 29-49.

Hertanto, E. (2017). Perbedaan Skala Likert Lima Skala dengan Modifikasi Skala Likert Empat Skala. Metodologi Penelitian, 1-4.

Huseman, R. C., Hatfield, J. D., \& Miles, E. W. (1987). A new perspective on equity theory: The equity sensitivity construct. Academy of management Review, 12(2), 222-234.

Nisa, Y. A. (2020). Pengaruh Love of Money, Machiavellian, Idealisme dan Religiusitas pada Persepsi Etis Mahasiswa Akuntansi. Prisma (Platform Riset Mahasiswa Akuntansi), 1(3), 64-73.

Kurniawan, A., \& Anjarwati, A. (2020, March). Does Love of Money, Machiavellian, Religiosity, Socioeconomic Status, and Understanding of the Accountant's Code of Ethics Affect the Ethical Perception of Accounting Students? In 1st International Conference on Accounting, Management and Entrepreneurship (ICAMER 2019) (pp. 33-37). Atlantis Press.

Lili Cahyani, N. W. S., \& Ramantha, I. W. (2018). Pengaruh Pengetahuan, Sensitivitas Etis, Idealisme pada Persepsi Etis Mahasiswa Akuntansi Atas Perilaku Etis Akuntan. E-Jurnal Akuntansi Universitas Udayana, 24(2), 1387.

Moshman, D. (2011). Adolescent rationality and development: Cognition, morality, and identity. Taylor \& Francis.

Nida, F. L. K. (2013). Intervensi Teori Perkembangan moral Lawrence Kohlberg dalam dinamika pendidikan karakter. Edukasia: Jurnal Penelitian Pendidikan Islam, 8(2). 271-290.

Prabowo, P. P., \& Widanaputra, A. P. (2018). Pengaruh Love of Money, Machiavellian, dan Idealisme pada Persepsi Etis Mahasiswa Akuntansi. E-Jurnal Akuntansi, 23(1), 513-537.

Reding, K. R., Sobel, P. J., Anderson, U. L., Head, M. J., Ramamoorti, S., Salamasick, M., \& Riddle, C. (2013). Internal Auditing: Assurance \& Advisory Services. Institute of Internal Auditors Research Foundation.

Rumpf, H. (1990). The characteristics of systems and their changes of state disperse. Part. Technol., Chapman, and Hall, 8-54.

Saitri, P. W., \& Suryandari, N. N. A. (2017). Pengaruh machiavellian, pembelajaran etika dan sikap etis akuntan dan mahasiswa akuntansi di denpasar. Jurnal Ilmiah Akuntansi dan Bisnis, 2(1), 175-190.

Sari, N. L. P. W. A., \& Widanaputra, A. A. G. P. (2019). Pengaruh Love of Money, Equity Sensitivity, dan Machiavellian Pada Persepsi Etis Mahasiswa Akuntansi. E-Jurnal Akuntansi, 28(2), 1522-1549.

Siregar, S. (2013). Metode Penelitian Kuantitatif. Jakarta: PT Fajar Interpratama Mandiri.

Susanti, B. (2014). Pengaruh Locus of Control, Equity Sensitivity, Ethical Sensitivity Dan Gender Terhadap Perilaku Etis Akuntan (Studi Empiris Kantor Akuntan Publik Wilayah Padang dan Pekanbaru). Jurnal Akuntansi, 2(3).

Tirto.id. (2018). Kasus SNP Finance dan Pertaruhan Rusaknya Profesi Akuntan Publik. Https://Tirto.Id/KasusSnp-Finance-Dan-Pertaruhan-Rusaknya- Reputasi-Akuntan-Publik-C4RT. https://tirto.id/kasus-snpfinance-dan- pertaruhan-rusaknya-reputasi-akuntan-publik-c4RT 
Jurnal Ekonomi, Bisnis dan Pendidikan, 1(2), 2021, 172-182

Winarno, B. (2014). Kebijakan publik, teori, proses, dan studi kasus (cetakan kedua). Yogyakarta: Center of Academic Publishing Service, CAPS. 